\title{
SIR FREDERIC GEORGE KENYON
}

Sir Frederic George Kenyon, G.B.E., K.C.B., D.Litt., F.B.A., who was President of this Society from I 934 to I939, died on Saturday 23 rd August 1952 at the age of 89 years. He was the last survivor of the fifteen children of the late John Robert Kenyon, Q.C., Vinerian Professor of Law in the University of Oxford. He was only third in descent from the first Lord Kenyon who succeeded Lord Mansfield as Lord Chief Justice in I 788.

Kenyon was educated at Winchester and New College, Oxford, being a scholar of both foundations. He was elected a Fellow of Magdalen in I 883, and in the same year entered the British Museum as Assistant in the Department of Manuscripts. He rapidly made a name for himself as a papyrologist, and discovered Aristotle's lost Treatise on the Athenian Constitution, and other texts. These discoveries established Kenyon's reputation as a scholar for life. For the next few years he continued his work on the publication of ancient texts, including the catalogue of Greek papyri in the Museum.

In I 909 he was appointed Director and Principal Librarian. Kenyon's long term of office proved him to be a wise and firm administrator. His directorship put an end to his studies in papyri, but he had developed a new, and to anyone who did not know him personally, rather an unusual interest for a scholar-in the Territorial Army. This he joined at an age when most men retire, and he served as commander of a training battalion in England during the war of 1914-18. There are many who will never forget his personally conducted route marches which were designed to make or break.

A list of the many bodies to which he belonged, and which he so generously served, both on Committees or as President, would fill a page of this journal. It is only possible to mention a few of these which are most closely connected with this Society. Besides being President of this Society he was President of the Society for the Promotion of Hellenic Studies from I 9 I 9 to I 924 ; President of the British School of Archaeology at Jerusalem since I 920; also of the Bibliographical Society, I 924-6 (Gold Medal, I 935); of the Navy Records Society, 1 924-48; Society for the Protection of Science and Learning, I 938-44; Friends of the National Libraries since I 93 I; the National Central Library; the Surrey Record Society since I943, and Surrey Archaeological Society since I 944. He was a Trustee of the Imperial War Museum I 920-46, and adviser to the Imperial War Graves Commission.

During the recent war he was a member of the Macmillan Committee for the Preservation of Works of Art in Enemy Hands, and had prepared himself for the task by accepting an invitation from the Spanish Republican Government to visit Spain during their Civil War to see the precautions which were being taken by that side to safeguard historical and artistic works in their territory. On this occasion he amazed the writer of this memoir by his extraordinary ability to stand up to the long and repeated journeys in the intense heat of a Spanish August in his middle seventies. 
Among his publications were Aristotle's Constitution of Athens, I 89I; Classical Texts from Papyri in the British Museum (Herodas, Hyperides, etc.), I 89 I ; Hyperides, Orations against Athenogenes and Philippides, 1892; Catalogue of Greek Papyri in the British Museum (1893, 1898, and 1907); Our Bible and the Ancient Manuscripts, 1895 (revised edition 1939); The Brownings for the Young, 1896; joint-editor of R. Browning's Poems, I 896; Bacchylides, I 897; Letters of E. B. Browning, 1897; Poems of E. B. Browning, 1 897; Palaeography of Greek Papyri, I 899; Facsimiles of Biblical Manuscripts in the British Museum, I 900; Handbook of the Textual Criticism of the New Testament, I 90 I (new edition I 9 I 2); Robert Browning and Alfred Domett, I 906; Hyperides (text), I 907; editor of Centenary Edition of R. Browning, I912; The Buildings of the British Museum, 1914; New Poems of $R$. and E. Browning, I9I4 (a personal side-line); Ancient Books and Modern Discoveries, 1928; Libraries and Museums, 1930; Books and Readers in Ancient Greece and Rome, I932; Recent Developments in the Textual Criticism of the Greek Bible, 1933; The Chester Beatty Biblical Papyri, 1933, I 934, I 935, I 936, I 937, and I 94I; Locke on Education (Roxburghe Club), I 934; The Story of the Bible, 1 936; The Text of the Greek Bible, 1937; The Bible and Archaeology, I 940; The Reading of the Bible, I 944; and The Bible and Modern Scholarship, I 948. In the last few months of his life he wrote a history of the British Academy, of which he was the sole surviving original Fellow. He served it as President and for many years as Secretary to within a short time of his death.

Honours naturally flowed freely upon a man as active as he was. He was Gentleman Usher of the Purple Rod of the Order of the British Empire, I9 I8; M.A., D.Litt. (Oxford, Durham, and Athens); Litt.D. (Cambridge and Dublin); LL.D. (St. Andrews, Wales, and Princeton); L.H.D. (Kenyon Coll., Ohio); Ph.D. (Halle); Doctor hon. Univ. of Paris (1927) and Brussels (1930); Corr. Member of the Royal Irish Academy, and numerous foreign academies.

Despite the number of his books and the committees in which he took an active part, he will be remembered as a man of very few words. When he took the chair at the meetings of this Society, compliments did not flow from him freely. His remarks before and after papers were usually terse. He joined the Society when he was over sixty years of age, but was obviously marked from the first for the Presidential Chair to which he was elected in 1934. During his period of office the number of Fellows increased and projects of excavation were pushed forward. It was at this time that the British Museum was raising funds to buy the Codex Sinaiticus, an object very close to his heart.

In private life he showed quite another side to his character. When in the company of friends he took a lively part in the conversation and his characteristic laugh would ring out. His fund of sardonic humour was fully displayed in the minutes which he wrote for one of the dining societies to which he belonged. $\mathrm{He}$ was never known to be late for an appointment. 